\title{
Circulating Endothelial Cell Protein C Receptor: Endothelial Regulation and Cumulative Impact of Gender and A3 Haplotype
}

\author{
Christophe Guitton ${ }^{\mathrm{a}-\mathrm{c}}$ Nathalie Gérard ${ }^{\mathrm{a}, \mathrm{c}}$ Thibaut Quillard ${ }^{\mathrm{a}, \mathrm{c}}$ \\ Béatrice Charreau ${ }^{\mathrm{a}, \mathrm{c}}$
}

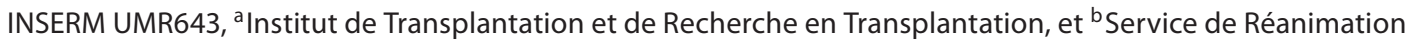

Médicale, ${ }^{C} \mathrm{CHU}$ de Nantes, Faculté de Médecine, Université de Nantes, Nantes, France

\section{Key Words}

Endothelial cells $\cdot$ Endothelial cell protein $\mathrm{C}$ receptor .

Inflammation · Tumor necrosis factor- $\alpha \cdot$ Ectodomain shedding

\begin{abstract}
Background: The endothelial cell $(E C)$ protein $C$ receptor (EPCR) negatively regulates coagulation and inflammation. Factors and mechanisms regulating the expression of cellbound EPCR and the release of soluble (s) EPCR are still unclear. Methods: We investigated the reciprocal regulation of membrane-bound and SEPCR upon inflammation using primary cultures of vascular EC. The impact of 2 parameters, gender and EPCR gene $A 3$ haplotype, on sEPCR plasma basal level and endothelial expression was examined by Elisa and flow cytometry. Results: Exposure of EC to tumor necrosis factor $\alpha$ causes a rapid downregulation of membrane-associated EPCR expression without affecting markedly the spontaneous release of sEPCR by EC. In a cohort of 100 healthy donors, we show that males express significantly higher basal sEPCR in plasma than females (194 \pm 12 vs. 145 $\pm 9 \mathrm{ng} / \mathrm{ml}$, respectively, $\mathrm{p}<0.01)$. Both gender and EPCR A3 haplotype affect sEPCR plasma levels but have no apparent effect on EPCR expression by EC. No quantitative correlation between cellular expression and circulating blood SEPCR
\end{abstract}

was observed, suggesting that endothelial expression may not reflect the plasma level. Conclusion: Male gender is another parameter with $\mathrm{A} 3$ haplotype associated with elevated sEPCR levels in blood, and both parameters may contribute to selective regulatory mechanisms of EPCR release upon inflammation.

Copyright ๑ 2011 S. Karger AG, Basel

\section{Introduction}

The protein C (PC) anticoagulant pathway is a major system that prevents blood coagulation; its impairment is known to influence vital outcome in severe inflammatory diseases such as sepsis $[1,2]$. This pathway involves 2 circulating proteins, PC and protein S [3], and 2 endothelial receptors, thrombomodulin [4] and the endothelial cell (EC) protein $\mathrm{C}$ receptor (EPCR). Conversion of PC to activated PC is initiated by thrombin bound to thrombomodulin on EC surfaces. Binding to EPCR increases the rate of $\mathrm{PC}$ activation by thrombin-thrombomodulin complexes [5]. Once activated, PC has anticoagulant effects but also exhibits anti-inflammatory $[6,7]$ and antiapoptotic effects $[8,9]$. Recent findings demonstrate that EPCR also serves as a cellular binding site for factor VII/factor VIIa [10]. Factor-VIIa-EPCR binding re-

\section{KARGER}

Fax +4161306 1234

E-Mail karger@karger.ch

www.karger.com
(C) 2011 S. Karger AG, Basel

1018-1172/11/0484-0336\$38.00/0

Accessible online at:

www.karger.com/jvr
Dr. Béatrice Charreau

INSERM UMR643

30, boulevard J.-Monnet

FR-44093 Nantes Cedex 01 (France)

Tel. +332 400874 16, Fax +33 2400874 11, E-Mail Beatrice.Charreau@ univ-nantes.fr 
duces factor VIIa coagulant activity and facilitates factor VIIa endocytosis and clearing from vessels [11].

EPCR (CD201) is a 46-kDa type I transmembrane protein, which is expressed mainly on the luminal surface of EC from large vessels and which is homologous to major histocompatibility complex class I/CD1 family proteins [12]. Disruption of the EPCR gene in mice causes placental thrombosis and early embryonic lethality confirming the key role for EPCR in controlling coagulation [13].

In addition to a transmembrane cell-bound form, a soluble form of EPCR (sEPCR) has been described in plasma [14]. sEPCR can be generated by ectodomain shedding [15] mediated by TACE/ADAM17 [16] or/and by alternative mRNA splicing in haplotype-A3-carrying cells [17]. sEPCR binds both PC and activated PC with an affinity similar to that of membrane EPCR [18]. Binding of activated PC to sEPCR interferes with binding of activated $\mathrm{PC}$ to phospholipids and inactivation of factor Va. Furthermore, binding of PC to sEPCR does not enhance activated $\mathrm{PC}$ generation, suggesting a procoagulant effect of sEPCR $[11,19]$.

EPCR levels vary in a wide variety of pathophysiological conditions, and the consequences depend partly on whether it is the membrane-associated or soluble form that is affected $[14,20,21]$. While the role of membraneassociated EPCR is clearly antithrombotic and anti-inflammatory in physiological circumstances, the function of the circulating sEPCR remains unclear.

Regulation of circulating sEPCR versus cell-bound EPCR in physiological condition and upon inflammatory disease has not been determined. Although the EPCR gene $\mathrm{A} 3$ haplotype has recently been found to be a major determinant of sEPCR levels in blood, only few data are yet available concerning its effect on EPCR expression at the EC surface. Moreover, whether other factors affect cellular and circulating EPCR is still unknown. In the present study, we first investigated the reciprocal regulation of membrane-bound EPCR and sEPCR upon inflammation using a collection of primary cultures of vascular EC. Next, the impact of 2 parameters, gender and $E P C R$ gene A3 haplotype, that we found to affect sEPCR plasma basal levels were further examined.

\section{Materials and Methods}

\section{Cell Culture and Reagents}

Forty-five primary cultures of human arterial EC were isolated from organ transplant donors at the time of transplantation and characterized as we previously reported [22]. For activation, confluent EC monolayers were cultured with human tumor ne- crosis factor- $\alpha$ (TNF- $\alpha$ ), interleukin (IL)-1 $\beta$ or interferon (IFN)$\gamma$ (both from R\&D Systems, Lille, France). Primary cultures were used between passages 2 and 5 . When applicable, cells were preincubated with inhibitors for $1 \mathrm{~h}$ before incubation with TNF- $\alpha$. Actinomycin D, cycloheximide and galardin were purchased from Calbiochem (St-Quentin-Fallavier, France).

Blood Sampling

Blood samples from healthy adult blood donors ( $\mathrm{n}=100$ individuals) were provided by the Etablissement Français du Sang (Nantes, France) and used as controls. Blood samples from braindead transplant donors $(n=18)$ were collected at the time of organ procurement concomitant to EC isolation.

\section{Research Ethics}

Informed consent was obtained prior to blood collection and before inclusion in this study for the collection and storage of cells, isolation of DNA and determination of gene polymorphisms. The study was approved by the local medical and ethical committee (Nantes University Hospital, France).

\section{DNA Isolation and EPCR Genotyping}

Genomic DNA was extracted from cultured EC $\left(3 \times 10^{6}\right.$ cells $)$ using the proteinase $\mathrm{K} / \mathrm{phenol-chloroform} \mathrm{method.} \mathrm{The} \mathrm{frequen-}$ cy of the A3 haplotype of the EPCR gene was screened using the $-1651(\mathrm{C} / \mathrm{G})$ polymorphism. The upstream primer $5^{\prime}-\mathrm{GCT}$ GAAATTTTGTATTCTGTCC-3' and the downstream primer 5' -CCAGTATAATGGCTACATTTTACC-3' were previously described [21].

\section{RNA Analysis and RT-PCR}

RNA was isolated using Trizol reagent (Invitrogen, Carlsbad, Calif., USA) and treated with Turbo DNase ${ }^{\circledR}$ (Ambion, Austin, Tex., USA) before reverse transcription (RT). Semiquantitative PCR for EPCR and GAPDH was carried out for 25-30 and 20 cycles, respectively, as follows: $94^{\circ} \mathrm{C}$ for $30 \mathrm{~min}, 60^{\circ} \mathrm{C}$ for $30 \mathrm{~min}$ and $72^{\circ} \mathrm{C}$ for $30 \mathrm{~min}$, with a final extension at $72^{\circ} \mathrm{C}$ for $3 \mathrm{~min}$. PCR primers were: sense EPCR4993For $5^{\prime}$-CCCAGACACCAACACCACG-3', antisense EPCR7320Rev 5'-GTCTGTCTTTGGAGGATGGGCC-3' for EPCR, and sense $5^{\prime}$-TCATCCCTGCCTCTACTG-3', antisense 5'-CACCACCCTGTTGCTGTA-3' for GAPDH. PCR products were separated on a $1.5 \%$ agarose gel in the presence of ethidium bromide.

Quantitative PCR was performed using the ABI Prism 7700 and 7900 sequence detection application program (PE Applied Biosystems, Foster City, Calif., USA). Relative expression was calculated according to the $2^{-\Delta \Delta \mathrm{Ct}}$ method, as previously described [23]. Custom primers for EPCR (for EPCR1U: 5'-GCGGAAAACACGAAAGGGAG-3' and EPCR1L 5'-CAGTGGGCAGATGTGGGAGA-3') were obtained from MWG (High Point, N.C., USA). Primers and probes for the HPRT gene were purchased from Applied Biosytems (HPRT; Hs99999909_m1).

Elisa Assays for Membrane-Bound EPCR and sEPCR

For cellular Elisa, EC were grown to confluence and then treated with cytokines on 96-well plates. After treatment, cells were fixed in glutaraldehyde. EPCR detection was achieved using antiEPCR goat IgG (R\&D Systems) at $5 \mu \mathrm{g} / \mathrm{ml}$ and revealed using peroxidase-labeled anti-goat antibodies (Serotec, Martinsried, Germany). Quantification of sEPCR in plasma samples and cul- 
ture supernatants was carried out using Elisa kits (Asserachrom, Stago-Diagnostica, France), performed in duplicates according to the manufacturer's instructions.

Fluorescence-Activated Cell Sorting Analysis

After treatment, EC were harvested and incubated with primary antibodies $(10 \mu \mathrm{g} / \mathrm{ml})$ for $30 \mathrm{~min}$ at $4{ }^{\circ} \mathrm{C}$. Monoclonal antibody against human vascular cell adhesion molecule 1 (VCAM-1) and polyclonal goat anti-EPCR antibodies were from R\&D Systems. Then, cells were stained $\left(30 \mathrm{~min}, 4^{\circ} \mathrm{C}\right)$ with a FITC- or PElabeled secondary IgG $\mathrm{F}\left(\mathrm{ab}^{\prime}\right)_{2}$ antibody (Jackson Laboratories, West Grove, Pa., USA). Irrelevant isotype-matched antibodies were used as negative controls.

Western Blot Analysis

Cell lysis was performed in lysis buffer containing $100 \mathrm{mM}$ $\mathrm{NaCl}, 5 \mathrm{mM} \mathrm{MgCl}_{2}$ and $1 \%$ Nonidet- 40 in the presence of protease inhibitors (Protease Inhibitor Cocktail; Sigma, St-Quentin-Fallavier, France). Immunoblotting was performed using anti-EPCR, anti-VCAM-1 or anti-tubulin or anti-HLA-E primary antibodies (R\&D Systems) and appropriate peroxidase-conjugated secondary antibodies and detected using enhanced chemiluminescence ECL $^{\mathrm{TM}}$ analysis system (Amersham). For culture supernatant analysis, total protein gel staining was performed before blotting using SYPRO ${ }^{\circledR}$ Ruby (Sigma) to ensure equal protein loading. Staining was performed following the manufacturer's instructions and was detected using an UV transilluminator.

\section{Statistical Analysis}

Results from in vitro studies are expressed as means $\pm \mathrm{SD}$. Data were analyzed using Prism 4.0 software (Graph Pad), and statistical significance was determined using InStat 3.0 (Graph Pad). Group comparisons were made using two-tailed Student's t test, and analysis of variance when more than two conditions were compared. $\mathrm{p}$ values $<0.05$ were considered to be statistically significant.

\section{Results}

\section{Inflammation Downregulates Cell-Bound but Has No}

Effect on EPCR Shedding by Vascular EC

While regulation of membrane EPCR has been already documented [5], only few data are available concerning the regulation of its soluble form in normal and pathological conditions. Therefore, in the present study, the coordinated expression of both membrane and soluble forms of EPCR was concomitantly investigated on cultured vascular EC. Firstly, we confirmed that inflammation mediated by lipopolysaccharide, TNF- $\alpha$ or IL- $1 \beta$ decreases EPCR at the EC surface while no change was found in response to IFN- $\gamma$ (fig. 1a-c). The decrease was significant at $6 \mathrm{~h}$ and rose to a maximum $(25-30 \%$ of basal level) at $24 \mathrm{~h}$. Mechanistically, RT-PCR analysis demonstrates that decreased EPCR expression by TNF- $\alpha$ results from a downregulation at the mRNA level (fig. 1d).
In parallel experiments, quantification of sEPCR in the culture supernatants demonstrates a spontaneous, timedependent release of sEPCR by unstimulated cultured EC that reach a plateau level (5-fold increase, as compared to control, $\mathrm{p}<0.01)$ at $8 \mathrm{~h}$. Interestingly, TNF- $\alpha$ did not significantly affect the time course and the rate of sEPCR release (fig. 2a). The failure of TNF- $\alpha$ to regulate the shedding of EPCR from EC culture was confirmed by Western blots performed on culture supernatants (fig. 2b). Release of soluble HLA-E was used as a positive control for EC activation [24] and equal protein loading was confirmed by SYPRO staining. We also found that both inhibition of transcription with actinomycin D and inhibition of metalloproteinases using galardin abrogate the production of sEPCR by both resting and activated EC (fig. 2c). Together, these data indicate first that reduced EPCR surface expression on cytokine-activated EC does not result from an enhanced EPCR shedding, suggesting that inflammation does not trigger major changes in circulating sEPCR production.

\section{Variability of EPCR Expression at the Endothelial}

Level and Impact of EPCR A3 Haplotype

To further investigate factors and biological parameters affecting the expression and release of EPCR, we used a collection of primary cultures of vascular EC isolated, in our center, from brain-dead organ transplant donors at the time of organ procurement for kidney transplantation [24]. Our biocollection includes EC cultures available for polymorphism/phenotype comparative studies as well as the corresponding sera and plasma collected at the time of EC isolation.

Elevated levels of plasma sEPCR have been previously associated with the A3 haplotype of the EPCR gene [20, 25]. Consequently, the impact of the EPCR haplotype on $\mathrm{EC}$ expression and release was investigated further. The frequency of the A3 haplotype of the EPCR gene was screened using the $-1651(\mathrm{C} / \mathrm{G})$ polymorphism as previously reported [21] and as illustrated figure $3 \mathrm{a}$. We found that 7 out of the $45 \mathrm{EC}$ donors carry $1 \mathrm{~A} 3$ allele (A1/A3 or A2/A3). No A3/A3 homozygous carrier was found in our cohort. Endothelial expression of cell-bound and soluble forms of EPCR was investigated by flow cytometry and Elisa, respectively. A comparative analysis of 31 (out of the 45 cultures available) independent EC cultures, including cultures from the $7 \mathrm{~A} / \mathrm{A} 3$ individuals, is shown in figure 3b. EPCR expression at the cell surface for the 31 samples is shown in increasing order. These data highlight the variability of endothelial expression of EPCR at the cell surface and as soluble form for the individuals of the co- 


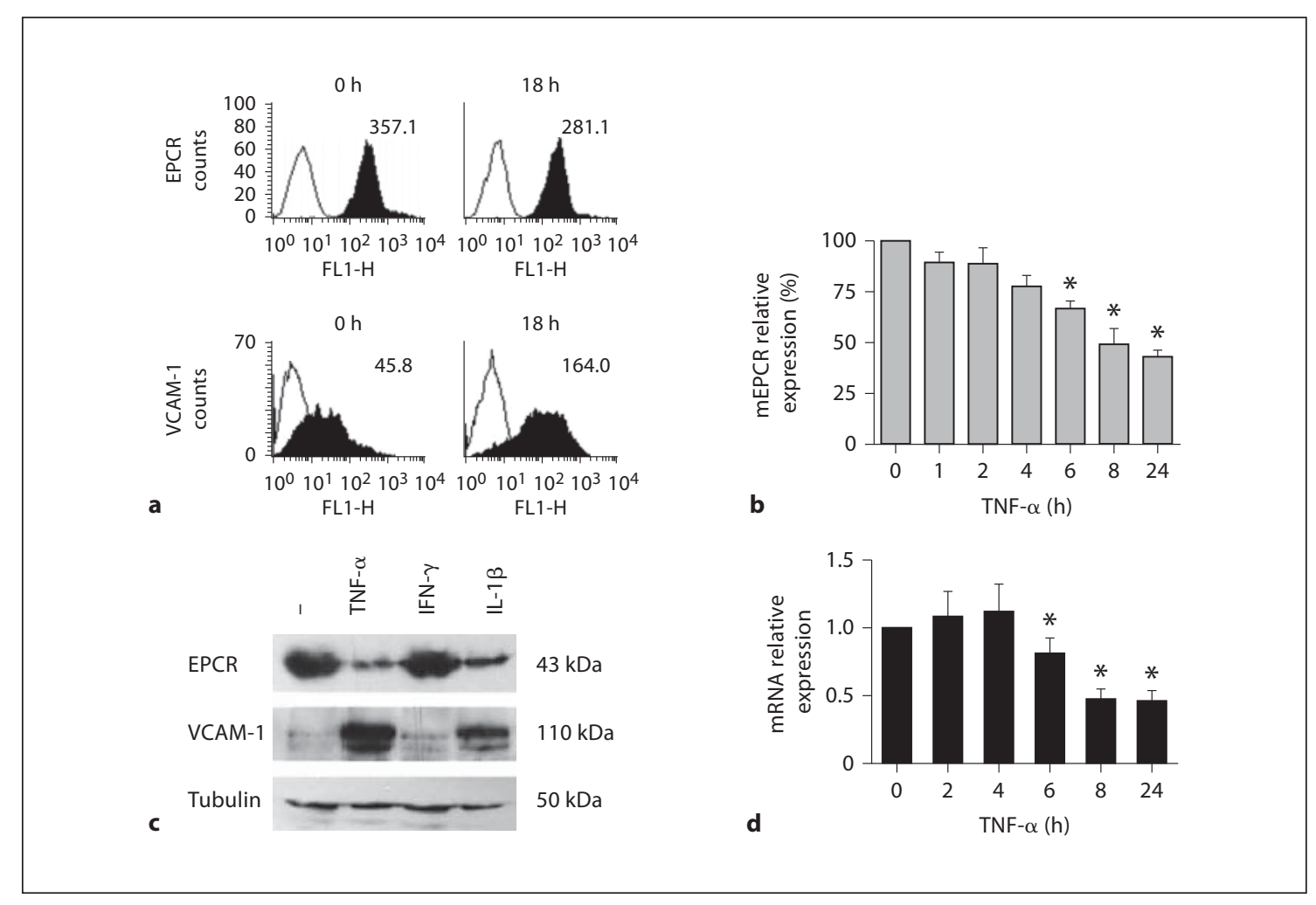

Fig. 1. Regulation of membrane EPCR on vascular EC upon inflammation. a Fluorescence-activated cell sorter analysis showing EPCR and VCAM-1 (black histograms) expression on EC treated with or without lipopolysaccharide $(5 \mathrm{ng} / \mathrm{ml})$ for $18 \mathrm{~h}$. Isotype-matched controls are shown as controls (white histograms). Values indicated are the medians of fluorescence intensity. b Time course analysis of membrane (m) EPCR expression on EC surface in response to TNF- $\alpha$ investigated by cellular Elisa. Relative expression was calculated using the optical density values, and re- sults are expressed as percentages of untreated cells; ${ }^{*} \mathrm{p}<0.05$ versus control. c Immunoblots for EPCR and VCAM-1 expression in lysates from EC treated with medium, TNF- $\alpha$ (100 U/ml), IFN$\gamma(100 \mathrm{U} / \mathrm{ml})$ or IL-1 $\beta(5 \mathrm{ng} / \mathrm{ml})$ for $24 \mathrm{~h}$. Blots were reprobed with an antitubulin antibody to ensure equal loading. d EPCR mRNA steady-state levels analyzed by real-time quantitative RT-PCR. Relative expression was calculated using $2^{-\Delta \Delta C t}$ after normalization to the housekeeping gene; ${ }^{*} \mathrm{p}<0.05$ versus control. All results are representative of at least 3 independent experiments. hort. This variability was similarly observed in both the $\mathrm{A} / \mathrm{A} 3$ and $\mathrm{A} / \mathrm{A}$ groups. Our results also indicate that the EPCR A/A3 haplotype does not correspond to a significant change in EPCR expression and release by EC compared to the EPCR A/A haplotype. Thus, these data further suggest a lack of positive or negative correlation, at the cell level for each individual, between membrane EPCR and sEPCR levels in EC supernatants. Indeed, the highest expression at the cell surface seems not associated with the highest or the lower release in cell culture supernatant.

\section{Differential Impact of EPCR A3 Haplotype on}

Circulating Blood sEPCR and on Cellular Expression

Next, we sought to determine whether circulating sEPCR levels in blood reflect membrane EPCR expression on EC. To address this question, we sought to deter- mine whether endothelial expression may correlate with circulating sEPCR in blood samples from the same individuals. For comparison, sEPCR was quantified in blood samples from $18 \mathrm{EC}$ donors, and then individuals were divided into 2 groups according to EPCR haplotype (A/A vs. A/A3). Consistently with previous reports [17, 20], significantly higher plasma levels of sEPCR were found in individuals with $1 \mathrm{~A} 3$ allele $(176.4 \pm 38.5 \mathrm{ng} / \mathrm{ml})$ as compared to those carrying the A1/A2 haplotype (57.4 \pm 40.6 $\mathrm{ng} / \mathrm{ml}$; fig. $4 \mathrm{a}, \mathrm{p}<0.05)$. Membrane and soluble forms of EPCR from EC cultures issued from A/A3 and A/A haplotype-carrying individuals were quantified by flow cytometry and Elisa assays, respectively. No significant difference in the level of EPCR on EC surface in A/A (mean of fluorescence intensity, MFI: $262 \pm 52, \mathrm{n}=24$ ) and A/ A3 (MFI: $269 \pm 65, \mathrm{n}=7$ ) individuals was observed 


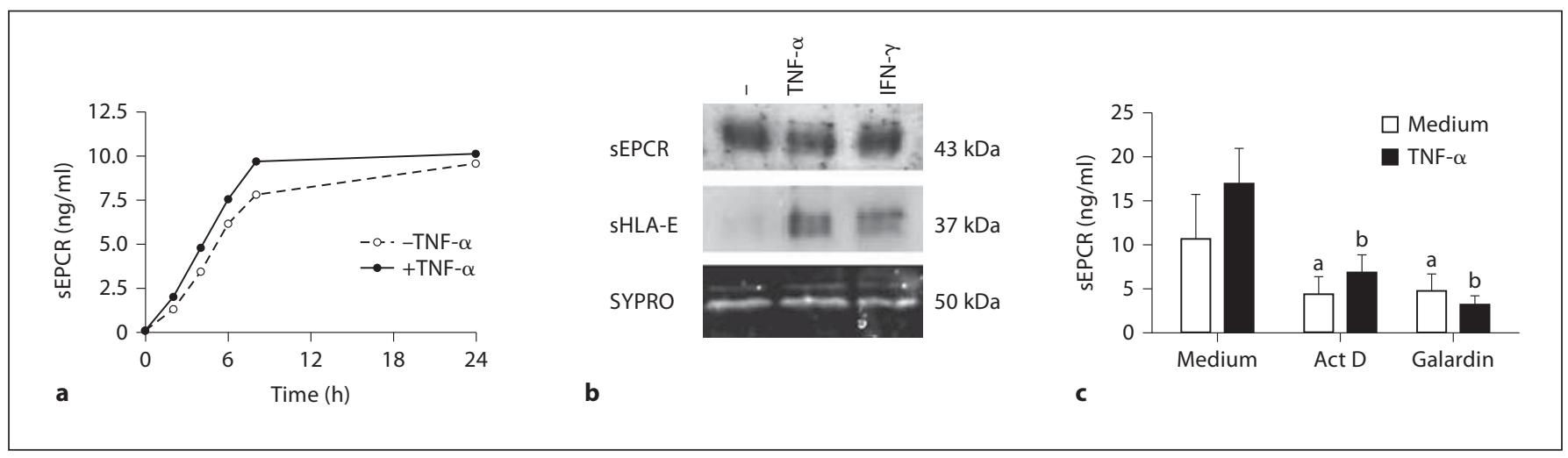

Fig. 2. Release of sEPCR by vascular EC upon inflammation. a Time-dependent release of sEPCR in supernatants from EC cultured with or without TNF- $\alpha$ and assessed by Elisa performed in triplicates. b Immunoblots for sEPCR in culture supernants from EC treated for $24 \mathrm{~h}$ with cytokines TNF- $\alpha$ (100 U/ml) or IFN- $\gamma$ $(100 \mathrm{U} / \mathrm{ml})$. For comparison, blots were reprobed with an antiHLA-E antibody. Before blotting, gel was stained with SYPRO
Ruby to ensure equal protein loading (lower panel). c Quantification of sEPCR by Elisa in culture supernatants from EC preincubated with actinomycin $\mathrm{D}$ (Act $\mathrm{D}, 0.2 \mathrm{U} / \mathrm{ml})$ or galardin $(100 \mathrm{U} /$ $\mathrm{ml}$ ) and then treated with or without TNF- $\alpha$ for $24 \mathrm{~h} ;{ }^{\mathrm{a}} \mathrm{p}<0.05$ versus untreated cells, ${ }^{\mathrm{b}} \mathrm{p}<0.05$ versus TNF-treated controls. EC used for these experiments carry the EPCR A/A haplotype. All results are representative of 3 independent experiments. (fig. 4b). Similarly, no difference was found in sEPCR levels in EC supernatants from non-A3 $(22.3 \pm 7.7 \mathrm{ng} / \mathrm{ml}$, $\mathrm{n}=24)$ and $\mathrm{A} 3(18.6 \pm 5.7 \mathrm{ng} / \mathrm{ml}, \mathrm{n}=7)$ subjects (fig. $4 \mathrm{c}$ ). Although these results remain to be confirmed in a larger cohort, our findings already indicate that elevated sEPCR plasma levels in A3 individuals may not correlate with higher endothelial expression of EPCR. Then, we investigated whether the EPCR haplotype may affect EPCR regulation upon cytokine stimulation and release in cell supernatant. The selective regulatory effect of TNF- $\alpha$ of membrane versus soluble forms of EPCR was further confirmed in this cohort of EC with no difference between A/A and A/A3 haplotypes (fig. 4d-f). A summary of the results issued from 7 individuals with the A/ A3 EPCR haplotype versus 24 individuals with the A/A EPCR haplotype is shown in figure $4 \mathrm{e}$. Data are expressed as means $\pm \mathrm{SD}$ of sEPCR levels in culture supernatants for $\mathrm{A} / \mathrm{A} 3$ and $\mathrm{A} / \mathrm{A}$ populations according to treatment (with or without TNF). The results illustrated in figure $4 \mathrm{f}$ show sEPCR rates in the individual corresponding culture supernatants $24 \mathrm{~h}$ after culture in medium alone or in medium supplemented with recombinant human TNF. This representation clearly underlines the variability of sEPCR rates according to cell/individual. The variability in the sEPCR rate is similarly observed in both groups (A/A3 and A/A), as also highlighted in figure $3 \mathrm{~b}$. To our knowledge, this is the first study documenting, in concomitant experiments, cellular and soluble forms of EPCR in a large panel of primary arterial EC cultures.
Thus, our study supports evidence for a lack of correlation between the EPCR A3 haplotype and SEPCR release by arterial EC, at least in culture, either at rest or stimulated with cytokines. Next, first attempts were made to examine whether the EPCR haplotype may affect molecular processes controlling the release of sEPCR. Firstly, by RT-PCR analysis, we confirmed the presence of an alternative splicing product (approx. $450 \mathrm{bp}$ ) in EC from A3 individuals as described recently [17] (fig. 4g). Next, RTPCR further indicates that TNF- $\alpha$ similarly downregulates transcripts for regular EPCR and its isoform (fig. 4h).

\section{Male Gender Is Another Parameter That Correlates with Elevated Blood Circulating sEPCR}

Although suspected from previously reported cohort studies [26, 27], the real impact of gender on EPCR was not clearly established. Our ongoing clinical study from septic patients suggests that male gender correlates with higher basal sEPCR [Guitton et al., manuscript in revision]. To address this point, plasma sEPCR was quantified by Elisa in 100 healthy donors (50 males and 50 females), and results were analyzed according to gender (fig. 5a). Our data clearly show that males express significantly higher sEPCR than females $(194 \pm 12$ vs. $145 \pm$ $9 \mathrm{ng} / \mathrm{ml}$ for males and females, respectively, $\mathrm{p}<0.01)$. A similar difference was found in the plasma samples from our cohort of EC donors although these data were not statistically significant due to the limited size of samples ( $\mathrm{n}=18,10$ males, 8 females, fig. 5b). Since no cells or DNA 
Fig. 3. Variability of EPCR expression by EC and influence of EPCR haplotype. a The frequency of the A3 haplotype of the EPCR gene was screened using the $-1651(\mathrm{C} / \mathrm{G})$ polymorphism. Wild-type (WT; -1651C/C; A/A) EPCR provides 2 fragments of 75 and $176 \mathrm{bp}$ while the $\mathrm{A} 3$ haplotype provides a full 251-bp fragment including the polymorphic site $(-1651 \mathrm{G} / \mathrm{C})$. b Comparative analysis of cell-bound EPCR and sEPCR in cultured EC ( $\mathrm{n}=31)$. Membrane EPCR was analyzed by fluorescence-activated cell sorting and expressed as means of fluorescence intensity (white bars). sEPCR were quantified by Elisa (data are expressed in nanograms per milliliter; gray bars). Samples were classified according to EPCR haplotype (A/A3 vs. A/A) and shown in increasing order of cell surface expression. All results are representative of 3 independent experiments.
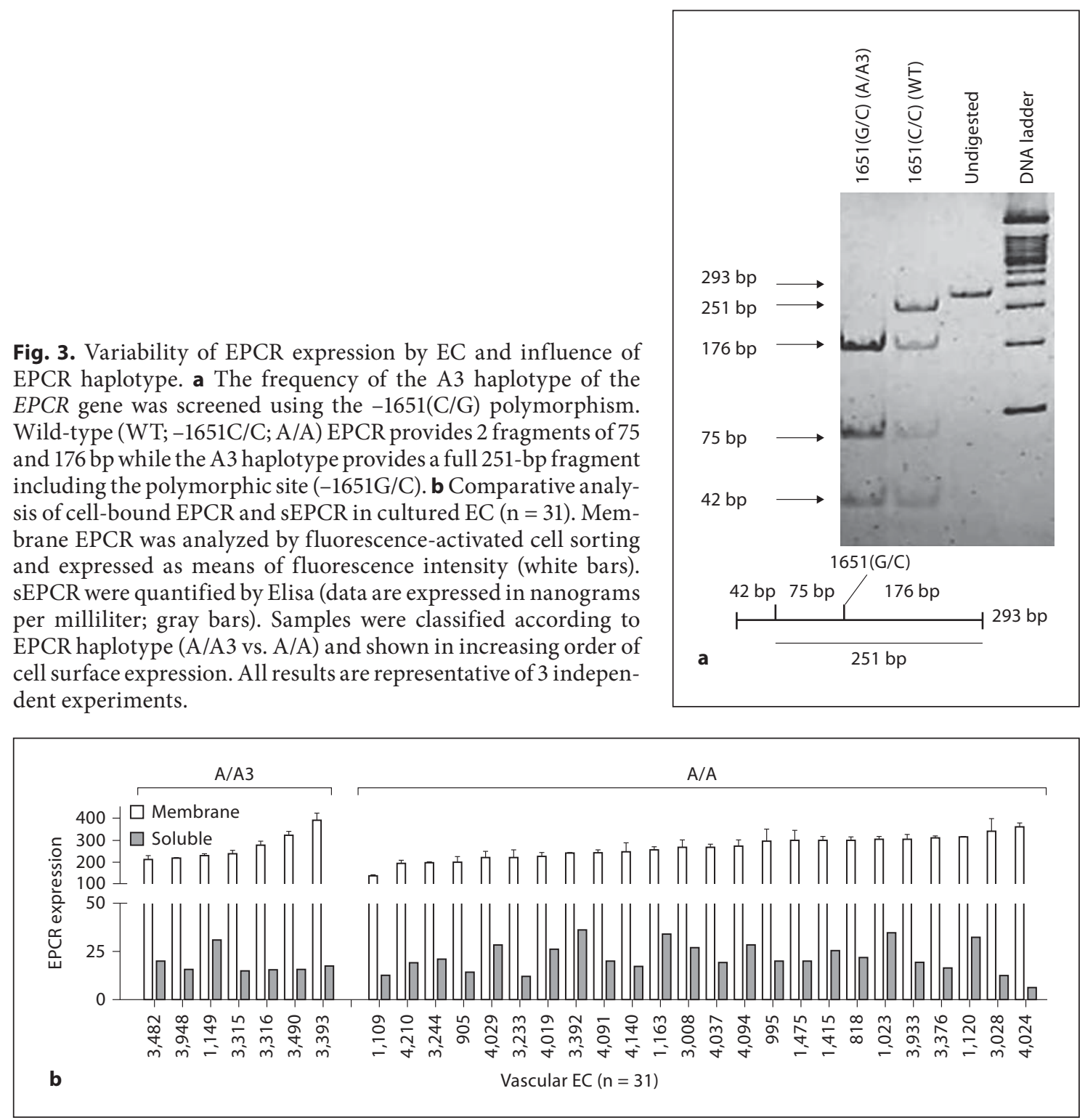

were available from the healthy donors for EPCR genetic analysis, the incidence of gender on endothelial expression of EPCR was studied in our cohort of EC cultures. A comparative analysis was performed to examine in cultured EC whether gender may control EPCR expression at the cell level. Investigation was conducted using $31 \mathrm{cul}-$ tures of EC, 14 from females and 17 from males. As shown in figure $5 \mathrm{c}$ and $\mathrm{d}$, we found no significant differences of membrane (MFI: $277 \pm 57$ for females vs. $253 \pm 51$ for males, respectively) and soluble EPCR levels in EC culture supernatants $(21.6 \pm 7.4 \mathrm{vs.} 21.4 \pm 7.6 \mathrm{ng} / \mathrm{ml}$ for females and males, respectively). These data further con- firm the lack of correlation between plasma levels and endothelial expression, at least in vitro.

We also found that gender does not affect TNF-mediated downregulation of cell-bound EPCR. However, a weak but significant downregulation of the soluble form in response to TNF was observed in females but not in males (fig. 5e, f). Finally, when the impact of gender on circulating blood EPCR rates was examined in relation to the EPCR A3 haplotype, the result shown in figure $5 \mathrm{~g}$ strongly supports the hypothesis that gender and EPCR A3 haplotype exert independent and cumulative impacts on basal circulating sEPCR levels. 


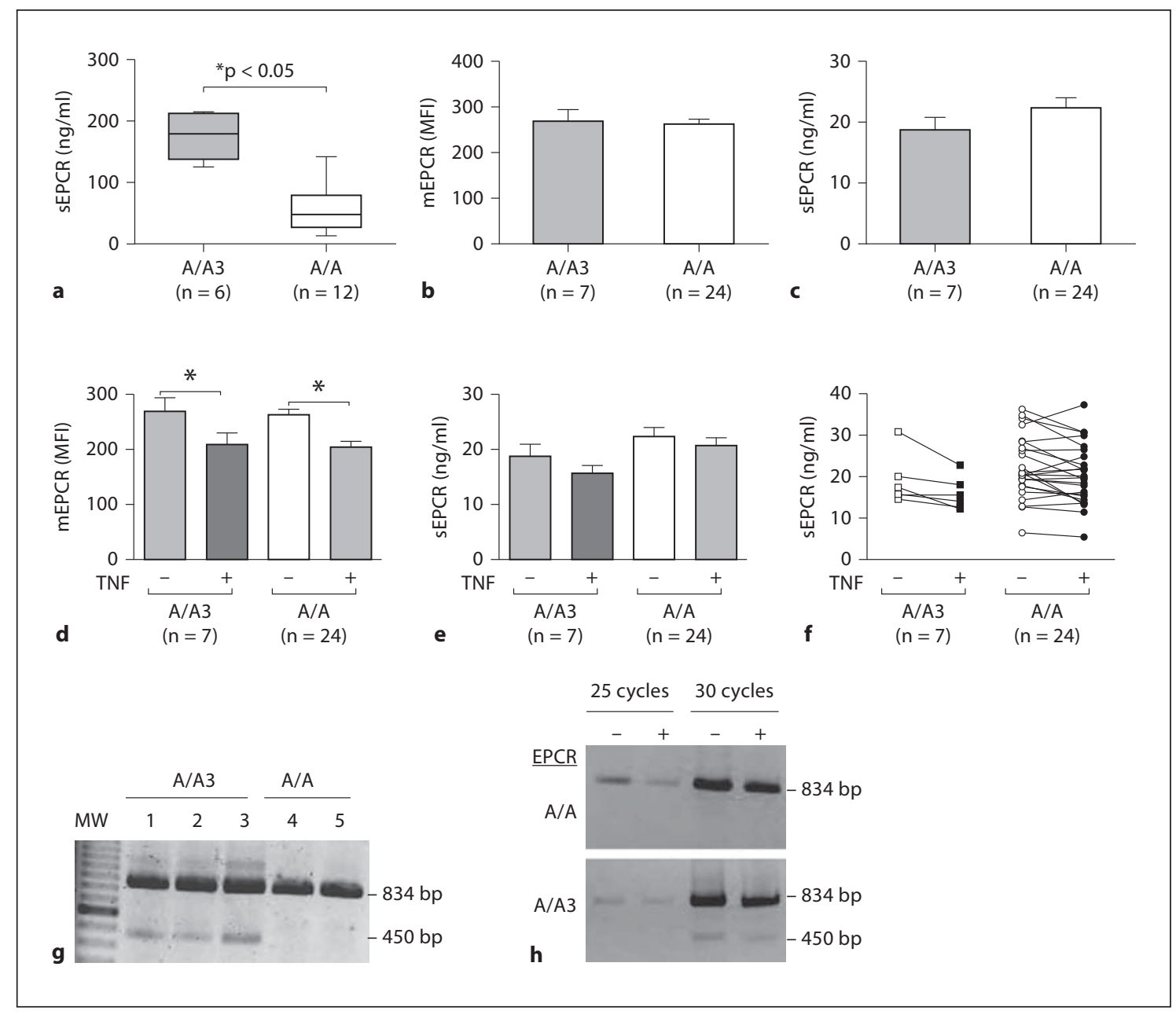

Fig. 4. Impact of EPCR A3 haplotype on blood sEPCR and endothelial expression. For comparison of plasma levels of sEPCR and endothelial expression, individuals $(\mathrm{n}=31)$ were divided into 2 groups (A/A3 and A/A) according to their EPCR haplotype. a Levels of sEPCR in blood from A/A versus A/A3 individuals as determined by Elisa. Results are shown as box blots. Expression of membrane (m) EPCR (b) and sEPCR (c) by the corresponding EC cultures was determined by fluorescence-activated cell sorting and Elisa, respectively. $\mathbf{d}-\mathbf{f}$ The regulatory effect of TNF- $\alpha$ was further analyzed in the cohort of EC donors $(n=31)$. Membrane
EPCR was analyzed by fluorescence-activated cell sorting and expressed as means of fluorescence intensity (MFI; d). sEPCR were quantified by Elisa $24 \mathrm{~h}$ after culture in medium alone or in medium supplemented with recombinant human $\operatorname{TNF}(\mathbf{e}, \mathbf{f})$. Global analysis of the cohort (e) and individual regulations (f) are shown. g RT-PCR analysis showing the full-length $(834 \mathrm{bp})$ and truncated (450 bp) transcripts in A3-carrying EC cultures. h Semiquantitative RT-PCR analysis showing the downregulation of both full-length and truncated EPCR mRNA in EC treated with (+) or without (-) TNF for $24 \mathrm{~h}$.
Together, these findings show that male gender is another parameter with the A3 haplotype associated with elevated levels in plasma EPCR in physiological conditions. We anticipate from our preliminary results that both gender and EPCR haplotype may contribute to selective regulation of soluble EPCR upon inflammation. This hypothesis still needs confirmation. Moreover, the mechanisms involved remain to be elucidated.

\section{Discussion}

EPCR is a key factor controlling coagulation through the binding of both PC and activated PC. Inhibition of EPCR binding of PC or activated PC was also found to exacerbate the septic response $[28,29]$. However, the clinical and functional impact of its soluble counterpart remains to be established. Here, we concomitantly exam- 


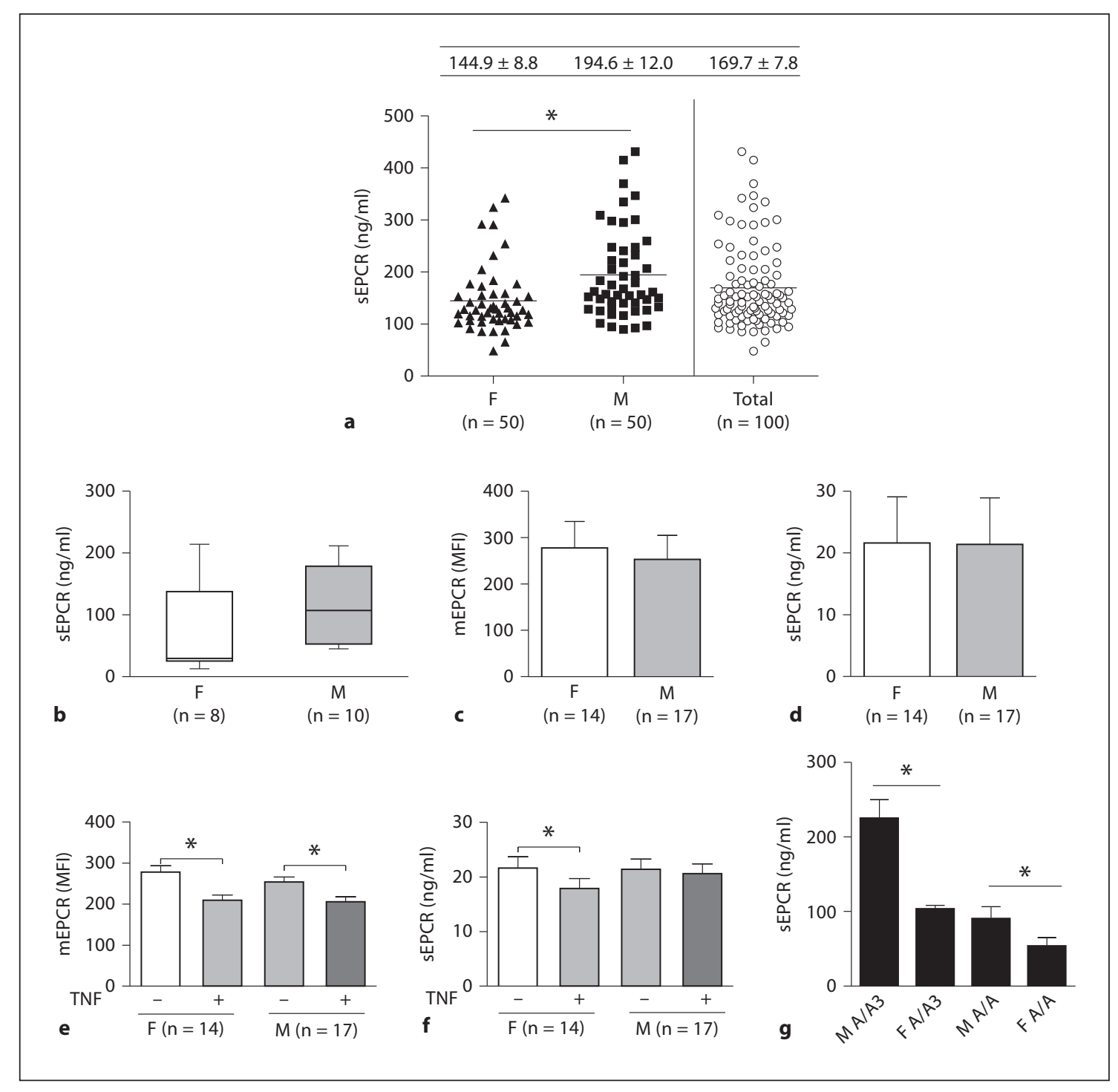

Fig. 5. Impact of gender on blood sEPCR and endothelial expression. a Effect of gender on sEPCR in physiological conditions was defined by quantifying sEPCR in blood samples from healthy donors - females $(F), n=50$; males $(M), n=50$; total, $n=100$ - by Elisa; ${ }^{*} \mathrm{p}<0.01$. Mean values \pm SEM are indicated. $\mathbf{b}-\mathbf{d}$ Comparison of plasma levels of sEPCR (b) and endothelial expression (c, d) from the same individuals according to gender. Comparative analysis of cell-bound (m) EPCR (c) and sEPCR (d) in cultured EC $(\mathrm{n}=31)$ according to gender. e, $\mathbf{f}$ The regulatory effect of TNF- $\alpha$ was further analyzed in the cohort of EC donors ( $\mathrm{n}=$ 31) according to gender. Membrane (m) EPCR was analyzed by fluorescence-activated cell sorting and expressed as means of fluorescence intensity (MFI) \pm SD. sEPCR in the corresponding cell supernatants $(\mathrm{n}=31)$ were quantified by Elisa and expressed as mean values \pm SD. g Quantitative analysis showing plasma levels of EPCR in A/A and A/A3 individuals according to gender; ${ }^{*} \mathrm{p}<$ 0.05 . Data shown are representative of 3 independent experiments. ined for the first time the regulation of both cellular and circulating forms of EPCR.

Firstly, our data suggest that the level of sEPCR is tightly controlled even upon inflammation in vivo. This hypothesis is supported by our results obtained using cultured vascular EC. Indeed, we found that in vitro inflam- mation downregulates the cell surface expression of EPCR without apparently affecting the production rate and kinetic of its soluble form. This result was initially obtained from EC cultures with the EPCR A/A haplotype (fig. 2), and similar data were found on EC with the A/A3 haplotype. Nevertheless, we cannot rule out the possibil- 
ity that shedding was higher in the presence of TNF- $\alpha$, thus compensating the lower number of membrane EPCR molecules in response to TNF stimulation. Indeed, since TNF downregulates membrane EPCR expression, one would expect, as a result, less shedding and therefore lower sEPCR levels. While EPCR is considered as a protective molecule, the function of its soluble form remains to be determined. Functionally, sEPCR bind PC and activated PC with high affinity $\left(K_{d}=75 \mathrm{nM}\right)[30]$ and thus may counteract (or balance) the anticoagulant action of membrane-associated EPCR. In previous studies, sEPCR levels in septic patients were found to be significantly higher [14, 31], similar [32] or even lower [33] than in healthy volunteers. These discrepancies may reflect the distribution of the A3 haplotype (15-20\%) among the cohorts since this haplotype is associated with higher baseline levels of sEPCR [20].

Our results also indicate that TNF-stimulated EC from either A/A3 or A/A EPCR individuals release similar levels of sEPCR. These findings are somewhere different from the results previously reported by Qu et al. [34]. From our point of view, this discrepancy can be explained as follows: experiments have not been performed on the same vascular cells (human umbilical vein EC vs. human arterial EC) and have used different stimulation (phorbol myristate acetate vs. TNF). Thus, we cannot rule out the possibility that regulation of EPCR may vary according to cell types and stimuli, as also suggested by $\mathrm{Qu}$ et al. Finally, the relatively high variability of EPCR expression and release among individuals that we show in the present study (fig. 3b and 4f) may also provide another explanation for these discrepancies. Indeed, our study gives a global analysis of EC cultures from 31 individuals including 7 carrying the $\mathrm{A} 3$ haplotype.

Another question that we addressed in this study is whether endothelial surface expression may predict plasma level. Surprisingly our data show no correlation between cell surface and sEPCR release by cultured EC. In other words, EC that express high levels of membranebound EPCR do not release high (or even lower) levels of sEPCR in culture supernatants. Furthermore, no correlation was found between endothelial expression and plasma level. Although no definite conclusion can be established given the relatively small sample size, these data may suggest that circulating sEPCR did not result only from EC. Consistently with this hypothesis, several studies demonstrated that other cell types express EPCR including monocytes [35] and smooth muscle cells [36]. However, the ability of these cells to produce sEPCR remains to be demonstrated. Alternatively, it seems likely that additional cell-specific mechanisms must be invoked in vivo for EC expression that may not occur in vitro.

In regard to parameters affecting sEPCR concentration, our results indicate that male gender is associated with elevated sEPCR compared to the female one. This difference occurs in physiological conditions. This finding results from the analysis of 100 healthy blood donors and still remains to be validated by larger cohor ts. Whether males and females respond differently to infection, either in terms of the host response or the eventual outcome, is critically important for both clinical care and the design of future clinical trials of anti-infective therapies. Although data from animal studies strongly suggest that male gender is a risk factor for an adverse outcome from infection, clinical data are still conflicting [37-39]. No difference in EPCR expression (cell-bound and soluble forms) was observed related to gender on cultured EC suggesting that this regulation of sEPCR occurs in vivo. The EPCR gene promoter contains several binding sites for several transcription factors including a thrombin response element (CCCACCCC), AP1, AP4 and multiple SP1 and several Ets (E26 transformation-specific sequence) sites [40, 41]. Ets domains are present in essentially all EC-specific gene promoters and play a pivotal role in the determination of endothelial characteristics [42] and emerging data also suggest a broader role for Ets transcription factors in endocrine pathophysiology [4]. Interestingly, Ets1 regulates the expression of some other mediators of coagulation (e.g. thrombin, plasminogen activator inhibitor 1 , thromboxane $\mathrm{A}_{2}$ receptor) [43]. Thus, whether Ets contribute to a gender-specific regulation of EPCR expression in EC should be tested.

Our study further confirms the major impact of the A3 haplotype on the sEPCR baseline level as previously reported $[17,20]$ and suggest that gender and A3 haplotype have a cumulative impact. We show here that TNF$\alpha$ downregulates both full-length and truncated transcript corresponding to the EPCR isoform in A3-carrying individuals. Mechanistically, we found that, in the presence of TNF- $\alpha$, inhibition of RNA synthesis (actinomycin D) strongly promotes the release of sEPCR by EC with the A3 haplotype while inhibition of protein synthesis (cycloheximide) promotes the release of sEPCR by EC with the A/A haplotype suggesting that haplotype-dependent regulatory mechanisms may occur (data not shown). Thus, our in vitro data indicate that a specific posttranscriptional regulation of the EPCR isoform may also occur. In particular, future experiments are needed to explore the molecular impact of A3 haplotype on the increased TNF-dependent release of sEPCR seen in the 
presence of inhibitors of the RNA synthesis in the A3 subjects and in the presence of inhibitors of protein synthesis in the non-A3 subjects.

To conclude, we demonstrate here that gender is another key factor with the A3 haplotype that determines sEPCR baseline in physiological conditions. In contrast, our experimental data strongly support the hypothesis that inflammation decreases the cell surface expression of EPCR but preserves the production rate and kinetic of its soluble form. Whether elevated sEPCR in patients correlates with a role for sEPCR in the pathogenesis of inflammatory diseases is still unknown.

\section{Acknowledgments}

This work was supported by grants from l'Agence de Biomédecine, la Société de Néphrologie, Lilly-France. This work was also in part supported by XENOME, an EU-funded Integrated Project in Life Sciences, Genomics and Biotechnology for Health (LSHB-CT-2006-037377) and by a grant from la Fondation de l'Avenir (contract ET8-498). The authors wish to thank Prof. George Karam and the team 'Coordination des prélèvements d'organes et de tissus' (ITUN, CHU de Nantes) for helpful contribution to tissue sample harvesting and Dr. Marianne Coste-Burel (Service de Virologie, CHU de Nantes) for helpful contribution with the blood sample collection.

\section{References}

1 Esmon CT: Protein C pathway in sepsis. Ann Med 2002;34:598-605.

$\checkmark 2$ Mackman N: Role of tissue factor in hemostasis, thrombosis, and vascular development. Arterioscler Thromb Vasc Biol 2004; 24:1015-1022.

-3 Braud VM, Allan DS, O'Callaghan CA, Soderstrom K, D'Andrea A, Ogg GS, Lazetic S, Young NT, Bell JI, Phillips JH, Lanier LL, McMichael AJ: HLA-E binds to natural killer cell receptors CD94/NKG2A, B and C. Nature 1998;391:795-799.

-4 Gutierrez-Hartmann A, Duval DL, Bradford AP: ETS transcription factors in endocrine systems. Trends Endocrinol Metab 2007;18: 150-158.

$\checkmark 5$ Fukudome K, Esmon CT: Identification, cloning, and regulation of a novel endothelial cell protein C/activated protein C receptor. J Biol Chem 1994;269:26486-26491.

6 Joyce DE, Gelbert L, Ciaccia A, De Hoff B, Grinnell BW: Gene expression profile of antithrombotic protein $\mathrm{C}$ defines new mechanisms modulating inflammation and apoptosis. J Biol Chem 2001;276:11199-11203.

7 Riewald M, Petrovan RJ, Donner A, Mueller BM, Ruf W: Activation of endothelial cell protease activated receptor 1 by the protein C pathway. Science 2002;296:1880-1882.

-8 Feistritzer C, Schuepbach RA, Mosnier LO, Bush LA, Di Cera E, Griffin JH, Riewald M: Protective signaling by activated protein $\mathrm{C}$ is mechanistically linked to protein $\mathrm{C}$ activation on endothelial cells. J Biol Chem 2006; 281:20077-20084.

-9 Isermann B, Vinnikov IA, Madhusudhan T, Herzog S, Kashif M, Blautzik J, Corat MA, Zeier M, Blessing E, Oh J, Gerlitz B, Berg DT, Grinnell BW, Chavakis T, Esmon CT, Weiler H, Bierhaus A, Nawroth PP: Activated protein $C$ protects against diabetic nephropathy by inhibiting endothelial and podocyte apoptosis. Nat Med 2007;13:1349-1358.
10 Ghosh S, Pendurthi UR, Steinoe A, Esmon CT, Rao LV: Endothelial cell protein C receptor acts as a cellular receptor for factor VIIa on endothelium. J Biol Chem 2007;282: 11849-11857.

11 Lopez-Sagaseta J, Montes R, Puy C, Diez N, Fukudome K, Hermida J: Binding of factor VIIa to the endothelial cell protein C receptor reduces its coagulant activity. J Thromb Haemost 2007;5:1817-1824.

12 Laszik Z, Mitro A, Taylor FB Jr, Ferrell G, Esmon CT: Human protein $C$ receptor is present primarily on endothelium of large blood vessels: implications for the control of the protein C pathway. Circulation 1997;96: 3633-3640.

13 Gu JM, Crawley JT, Ferrell G, Zhang F, Li W, Esmon NL, Esmon CT: Disruption of the endothelial cell protein $\mathrm{C}$ receptor gene in mice causes placental thrombosis and early embryonic lethality. J Biol Chem 2002;277: 43335-43343.

14 Kurosawa S, Stearns-Kurosawa DJ, Carson CW, D’Angelo A, Della Valle P, Esmon CT: Plasma levels of endothelial cell protein $\mathrm{C}$ receptor are elevated in patients with sepsis and systemic lupus erythematosus: lack of correlation with thrombomodulin suggests involvement of different pathological processes. Blood 1998;91:725-727.

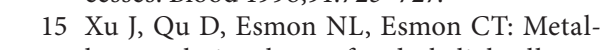
loproteolytic release of endothelial cell protein C receptor. J Biol Chem 2000;275:60386044.

16 Qu D, Wang Y, Esmon NL, Esmon CT: Regulated endothelial protein $\mathrm{C}$ receptor shedding is mediated by tumor necrosis factoralpha converting enzyme/ADAM17. J Thromb Haemost 2007;5:395-402.

17 Saposnik B, Lesteven E, Lokajczyk A, Esmon CT, Aiach M, Gandrille S: Alternative mRNA is favored by the A3 haplotype of the EPCR gene PROCR and generates a novel soluble form of EPCR in plasma. Blood 2008; 111:3442-3451.
18 Liaw PC, Neuenschwander PF, Smirnov MD, Esmon CT: Mechanisms by which soluble endothelial cell protein $\mathrm{C}$ receptor modulates protein $\mathrm{C}$ and activated protein $\mathrm{C}$ function. J Biol Chem 2000;275:5447-5452.

19 Esmon CT: The endothelial protein C receptor. Curr Opin Hematol 2006;13:382-385.

-20 Saposnik B, Reny JL, Gaussem P, Emmerich J, Aiach M, Gandrille S: A haplotype of the EPCR gene is associated with increased plasma levels of sEPCR and is a candidate risk factor for thrombosis. Blood 2004;103:13111318.

21 Simioni P, Morboeuf O, Tognin G, Gavasso S, Tormene D, Woodhams B, Pagnan A: Soluble endothelial protein $\mathrm{C}$ receptor (sEPCR) levels and venous thromboembolism in carriers of two dysfunctional protein $\mathrm{C}$ variants. Thromb Res 2006;117:523-528.

22 Coupel S, Leboeuf F, Boulday G, Soulillou JP, Charreau B: RhoA activation mediates phosphatidylinositol 3-kinase-dependent proliferation of human vascular endothelial cells: an alloimmune mechanism of chronic allograft nephropathy. J Am Soc Nephrol 2004;15:2429-2439.

23 Livak KJ, Schmittgen TD: Analysis of relative gene expression data using real-time quantitative PCR and the 2(-delta delta $\mathrm{C}(\mathrm{T})$ ) method. Methods 2001;25:402-408.

24 Coupel S, Moreau A, Hamidou M, Horejsi V, Soulillou JP, Charreau B: Expression and release of soluble HLA-E is an immunoregulatory feature of endothelial cell activation. Blood 2007;109:2806-2814.

25 Medina P, Navarro S, Estelles A, Vaya A, Woodhams B, Mira Y, Villa P, Migaud-Fressart M, Ferrando F, Aznar J, Bertina RM, Espana F: Contribution of polymorphisms in the endothelial protein $\mathrm{C}$ receptor gene to soluble endothelial protein $\mathrm{C}$ receptor and circulating activated protein $\mathrm{C}$ levels, and thrombotic risk. Thromb Haemost 2004;91: 905-911. 
-26 Stearns-Kurosawa DJ, Burgin C, Parker D, Comp P, Kurosawa S: Bimodal distribution of soluble endothelial protein $\mathrm{C}$ receptor levels in healthy populations. J Thromb Haemost 2003;1:855-856.

-27 Uitte de Willige S, Van Marion V, Rosendaal FR, Vos HL, de Visser MC, Bertina RM: Haplotypes of the EPCR gene, plasma sEPCR levels and the risk of deep venous thrombosis. J Thromb Haemost 2004;2:1305-1310.

-28 Taylor FB Jr, Stearns-Kurosawa DJ, Kurosawa S, Ferrell G, Chang AC, Laszik Z, Kosanke S, Peer G, Esmon CT: The endothelial cell protein $\mathrm{C}$ receptor aids in host defense against Escherichia coli sepsis. Blood 2000; 95:1680-1686.

-29 Taylor FB Jr, Peer GT, Lockhart MS, Ferrell G, Esmon CT: Endothelial cell protein C receptor plays an important role in protein $\mathrm{C}$ activation in vivo. Blood 2001;97:1685-1688.

-30 Preston RJ, Villegas-Mendez A, Sun YH, Hermida J, Simioni P, Philippou H, Dahlback B, Lane DA: Selective modulation of protein $\mathrm{C}$ affinity for EPCR and phospholipids by Gla domain mutation. Febs J 2005;272: 97-108.

-31 Liaw PC, Esmon CT, Kahnamoui K, Schmidt S, Kahnamoui S, Ferrell G, Beaudin S, Julian JA, Weitz JI, Crowther M, Loeb M, Cook D: Patients with severe sepsis vary markedly in their ability to generate activated protein $\mathrm{C}$. Blood 2004;104:3958-3964.
32 Faust SN, Levin M, Harrison OB, Goldin RD, Lockhart MS, Kondaveeti S, Laszik Z, Esmon CT, Heyderman RS: Dysfunction of endothelial protein $\mathrm{C}$ activation in severe meningococcal sepsis. N Engl J Med 2001;345: 408-416.

33 Borgel D, Bornstain C, Reitsma PH, Lerolle N, Gandrille S, Dali-Ali F, Esmon CT, Fagon JY, Aiach M, Diehl JL: A comparative study of the protein $\mathrm{C}$ pathway in septic and nonseptic patients with organ failure. Am J Respir Crit Care Med 2007;176:878-885.

34 Qu D, Wang Y, Song Y, Esmon NL, Esmon CT: The Ser219 $\rightarrow$ Gly dimorphism of the endothelial protein $\mathrm{C}$ receptor contributes to the higher soluble protein levels observed in individuals with the A3 haplotype. J Thromb Haemost 2006;4:229-235.

35 Galligan L, Livingstone W, Volkov Y, Hokamp K, Murphy C, Lawler M, Fukudome K, Smith O: Characterization of protein $\mathrm{C}$ receptor expression in monocytes. Br J Haematol 2001;115:408-414.

36 Bretschneider E, Uzonyi B, Weber AA, Fischer JW, Pape R, Lotzer K, Schror K: Human vascular smooth muscle cells express functionally active endothelial cell protein C receptor. Circ Res 2007;100:255-262.

37 Fine MJ, Smith MA, Carson CA, Mutha SS, Sankey SS, Weissfeld LA, Kapoor WN: Prognosis and outcomes of patients with community-acquired pneumonia: a meta-analysis. JAMA 1996;275:134-141.
38 Eachempati SR, Hydo L, Barie PS: Genderbased differences in outcome in patients with sepsis. Arch Surg 1999;134:1342-1347.

39 Adrie C, Azoulay E, Francais A, Clec'h C, Darques L, Schwebel C, Nakache D, Jamali S, Goldgran-Toledano D, Garrouste-Orgeas M, Timsit JF: Influence of gender on the outcome of severe sepsis: a reappraisal. Chest 2007;132:1786-1793.

40 Simmonds RE, Lane DA: Structural and functional implications of the intron/exon organization of the human endothelial cell protein $\mathrm{C} /$ activated protein $\mathrm{C}$ receptor (EPCR) gene: comparison with the structure of $\mathrm{CD} 1 /$ major histocompatibility complex alpha1 and alpha2 domains. Blood 1999;94: 632-641.

41 Rance JB, Follows GA, Cockerill PN, Bonifer C, Lane DA, Simmonds RE: Regulation of the human endothelial cell protein $\mathrm{C}$ receptor gene promoter by multiple Sp1 binding sites. Blood 2003;101:4393-4401.

42 Dejana E, Taddei A, Randi AM: Foxs and Ets in the transcriptional regulation of endothelial cell differentiation and angiogenesis. Biochim Biophys Acta 2007;1775:298-312.

$\checkmark 43$ Nakatsuka H, Sokabe T, Yamamoto K, Sato Y, Hatakeyama K, Kamiya A, Ando J: Shear stress induces hepatocyte PAI-1 gene expression through cooperative Spl/Ets-1 activation of transcription. Am J Physiol Gastrointest Liver Physiol 2006;291:G26-G34. 